\title{
Physical disability after retirement and occupa- tional risk factors during working life: a cross sectional epidemiological study in the Paris area
}

\author{
Bernard Cassou, Francis Derriennic, Yuriko Iwatsubo, Maurice Amphoux
}

\begin{abstract}
Study objective-The aim was to examine the relationship between exposure to occupational risk factors during working life and physical disability after retirement.

Design-The study was a cross sectional epidemiological survey of a representative sample of retired subjects belonging to a supplementary pension fund in the Paris area.
\end{abstract}

Setting-The study took place in the general community.

Patients-307 men and 320 women (63.1\% of those approached) answered a questionnaire during home interviews. Their average age was 69 (SD4) years at the beginning of the survey. Whether or not subjects had been exposed to occupational risks was determined from their statements concerning the presence or absence of eight harmful environmental conditions while at work. Physical disability was defined as difficulty in carrying out seven basic activities of daily life.

Main results-The results of univariate analyses showed significant relationships between exposure during working life to occupational risks including noise, heat, dust, carrying heavy loads, and awkward postures on the one hand, and the presence of a physical disability after retirement on the other. Multivariate analysis based on logistic regression models that took account of age, sex, and health impairments revealed a specific link between exposure to carrying heavy loads and physical disability after retirement.

Conclusions-These results suggest that occupational risk factors might be important in determining such disability in retired people.

Consultation de

Gérontologie Sainte

Périne, 49 rue

Mirabeau, 75016

Paris, France

B Cassou

INSERM U 170, 16 av

$P$ Vaillant-Couturier,

94807 Villejuif Cedex,

France

F Derriennic

Y Iwatsubo

GRASP, 15 rue

Claude Lorrain, 75016

Paris, France

M Amphoux

Correspondence to: Dr Cassou

Accepted for publication February 1992 favoured by cigarette smoking, alcohol consumption, and the absence of physical activity. ${ }^{9-11}$

The effect of each factor is complex. Education, for example, is probably mediated by numerous factors such as availability and use of health care services, quality of health care, lifestyle, and occupation. ${ }^{12}$

The respective parts played by the factors in causing physical disability are not yet clear, and other factors which might also help to generate such disability or intervene during its development do not seem to have been given sufficient attention. In particular, it is difficult at the present time to establish whether occupational risk factors have a long term effect on physical disability, and if so how. ${ }^{13}$

The present study was carried out within this framework, as we used data supplied by a prospective survey of the health of retired subjects living in the Paris area. Our aim was to verify the existence of a statistical link between certain occupational risk factors connected with the working environment or the work itself, and the presence of physical disability at the first phase of our survey.

\section{Methods}

This survey focused on 993 retired subjects (484 men and 509 women) aged 60 years and over, who were randomly selected from the files of an interprofessional supplementary pension fund (Institut de Prévoyance Sociale InterEntreprise). This fund manages pensions for more than 17000 beneficiaries who have had various occupations, most of them in companies specialising in metal conversion, commerce, and transport. All the subjects in the sample were living at home, in the Paris area. The interviews were carried out in subjects' homes by specially trained investigators, in 1982 or 1983.

Information about occupational exposure and health status was collected by means of a questionnaire. It concerned jobs, occupational risk factors experienced during working life, housing conditions, previous pathology, diseases at the time of interview and their symptoms and clinical signs, difficulties in personal care, difficulties of mobility, and need for assistance in pursuing daily activities.

Work histories were obtained from three sources. (1) The first source was interviews, using closed questions concerning previous occupational exposure to eight harmful environmental conditions: noise, heat, bad weather, dust, toxic products, carrying of heavy loads, awkward postures, and vibration. A subject was considered to have been exposed if he or she had been subject to 
one of these conditions for at least 10 years. (2) The second source was a detailed work history, obtained from an open questionnaire about job titles. The types of activity most pursued during working life were classified into four main categories of occupational status using the classification of the National Institute of Statistics and Economic Studies: white collar workers (top executives, junior executives and technical workers), clerks and salesmen, blue collar workers (foremen, skilled and unskilled workers, and workers in service), and others. (3) The third source was the pension fund. At the time of retirement, the pension fund retraces each member's occupational history by compiling a list of companies for which they have worked. A subject was considered to have been highly mobile when the number of different companies involved in the subject's occupational history and the number of branches of economic activity were both larger than the averages observed for the respondent as a whole. ${ }^{14}$

The questions about physical disability were adapted from previous studies. Disability was measured by the difficulties reported by subjects and by their dependence on assistance for seven basic activities of daily life. Only three of the activities proposed by $\mathrm{Katz}^{15}$ were assessed: dressing, going to the lavatory, and eating. Part of Rosow and Breslau's functional health scale ${ }^{16}$ was also included in the assessment: walking up and down stairs, and walking on flat ground, and two items used by Branch $^{17}$ (shaving and trimming of toenails).

We added all these items up to form an index. Subjects were divided into three categories: no difficulty or help needed for any of the seven activities of daily life; difficulties in one or more activity but no help needed in any of them; and help needed in one activity or more.

We distinguished five main types of impairment: (1) musculoskeletal impairment, defined as pains in the joints or spine for at least six months before the day of interview: (2) cardiorespiratory: presence of cough and expectoration for at least two years and at least three consecutive months each year, or presence of thoracic pains or palpitations hampering daily activities; (3) audiovisual: discomfort or difficulty in seeing or hearing sufficient to hamper daily activities (despite corrective lenses or hearing aid); (4) gastrointestinal: daily pains in the stomach or abdomen, or alternate constipation and diarrhoea; and (5) mental: at least five positive answers to nine

Table I Mean age, past occupational characteristics, and mortality of the men and women respondents and non-respondents. Values are means (SD).

\begin{tabular}{|c|c|c|c|c|c|c|}
\hline & \multicolumn{3}{|l|}{ Men } & \multicolumn{3}{|l|}{ Women } \\
\hline & $\begin{array}{l}\text { Respondents } \\
(n=317)^{\star}\end{array}$ & $\begin{array}{l}\text { Non- } \\
\text { respondents } \\
(n=164)\end{array}$ & $p$ & $\begin{array}{l}\text { Respondents } \\
(n=303)^{\star}\end{array}$ & $\begin{array}{l}\text { Non- } \\
\text { respondents } \\
(n=202)\end{array}$ & $p$ \\
\hline $\begin{array}{l}\text { Mean age } \\
\text { Mean number of } \\
\text { companies }\end{array}$ & $\begin{array}{r}68.5(3.7) \\
5.7(6.3)\end{array}$ & $\begin{array}{c}69.0(2.09) \\
6.1(5.9)\end{array}$ & $\begin{array}{l}\text { NS } \\
\text { NS }\end{array}$ & $\begin{array}{r}68 \cdot 5(3 \cdot 6) \\
6.5(7 \cdot 0)\end{array}$ & $\begin{array}{r}68.9(3.1) \\
5.7(5.0)\end{array}$ & $\begin{array}{l}\text { NS } \\
\text { NS }\end{array}$ \\
\hline $\begin{array}{l}\text { Subjects with high } \\
\text { mobility }(\%)\end{array}$ & 20.5 & $25 \cdot 6$ & NS & $27 \cdot 4$ & $22 \cdot 8$ & NS \\
\hline
\end{tabular}

Number of deaths \begin{tabular}{lcccccc} 
Percentage of deaths & 25.9 & 24.4 & NS & 8.1 & 9.9 & NS \\
Mean age at death & $73.6(5.3)$ & $\mathbf{7 4 . 0}(4.0)$ & NS & $\mathbf{7 4 . 8}(4.2)$ & $73.6(3.7)$ & NS \\
\hline *For three of the 320 men and four of the 307 .
\end{tabular} \begin{tabular}{llllllll} 
Mean age at death & $73.6(5.3)$ & $\mathbf{7 4 . 0}$ & NS & 8.1 & 9.9 & NS \\
\hline *For three of the 320 men and four of the 307 & NS & $\mathbf{7 4 . 8}(4.2)$ & $73.6(3.7)$ & NS \\
\hline
\end{tabular} 83
$25 \cdot 9$ 24: Mortality between 1981 and 1989 information supplied by the pension fund was not available, so that the statistical analysis, in this table only, concerned 317 men and 303 women. questions adapted from the scale proposed by Langner. ${ }^{18}$

Other factors taken into account were subjects' age, living alone, having an outside WC, and having to go up at least 10 stairs to enter the house. The sample is still being followed up for mortality.

\section{STATISTICAL ANALYSIS}

For all the relationships in which physical disability was classified into three categories (no difficulty in daily life activities, difficulty but no help needed, and difficulty requiring help) statistical significance was measured by the $\chi^{2}$ test for qualitative variables or by variance analysis for quantitative variables.

In a subsequent analysis, logistic regression models were used in order to take simultaneous account of the variables that the gross analyses showed to be linked to the frequency of physical disability. For these analyses, disability was dichotomised by separating the subjects who admitted to having a difficulty, with or without the need for help, in at least one basic daily activity from those who experienced no difficulty or need for help.

The explanatory variables were divided into three homogeneous subgroups. The first consisted of sociodemographic variables, coded as follows age (70 years or more $=1$, no $=0$ ); sex $(\mathrm{F}=1, \mathrm{M}=0)$; occupational status (blue collar, clerk, salesman, and others $=1$, white collar $=0$ ); living alone (yes $=1$, no $=0)$; outside $W C($ yes $=1$, no $=0$ ), and more than 10 steps to enter the house (yes $=1$, no $=0$ ). The second subgroup comprised the five types of impairment, each coded as 1 when present and 0 when absent. The third subgroup comprised the eight forms of occupational exposures considered, coded 1 or 0 depending on whether or not subjects had experienced them for 10 years during their working life.

We began by analysing physical disability using three separate models, as a function of the three groups of explanatory variables; we then collected into a general model all the variables with a significant $\beta$ coefficient in the separate models, to adjust the relationship between occupational exposure and physical disability to the other variables. Two general models were used: one included occupational status and the other did not. Each of the separate and general models was analysed by a stepwise forward procedure. The variables chosen were those that improved the maximum likelihood. Computer calculations were done with BMDP software.

\section{Results}

Table I shows that of the 993 subjects surveyed $627(63.1 \%)$ were respondents. On the basis of the information supplied by the pension fund, we compared respondents and non-respondents for age, number of firms for which they had worked, job mobility, and the type of branches of economic activity in which they had been employed. The mean ages of non-respondent men and women were 69.0 and 68.9 years respectively at the time of selection. The mean number of companies was 6.1 for the men and 5.7 for the women. The percentage of subjects with high 
mobility was 25.6 for the men and 22.8 for the women. The numbers were not significantly different from those observed among the respondents. Respondents and non-respondents did not differ significantly as regards sex, the type of branches of activity, and mortality among each sex (percentage of death during eight years follow up and mean age at death).

Table II shows the mean sociodemographic features of the subjects studied. In all, 320 men (response rate $66.1 \%$ ) and 307 women (response rate $60.3 \%$ ) were respondents. They were all retired, and were aged from 60 to 84 years, mean 69 (SD 4) years. Nearly $82 \%$ were aged from 65 to 75 years. On average, they were interviewed six years after retirement. Blue collar workers were the largest occupational status in the sample.

As shown in table III, indicating the prevalence of physical disability and impairments, $70 \%$ of the subjects interviewed experienced no difficulties and required no help for the seven basic activities of daily life considered. Nearly $20 \%$

Table II Main sociodemographic data

\begin{tabular}{|c|c|c|}
\hline $\begin{array}{l}\text { Sociodemographic } \\
\text { variables }\end{array}$ & $\begin{array}{l}\text { Number of } \\
\text { subjects }\end{array}$ & Percentage \\
\hline $\begin{array}{l}\text { Sex } \\
\text { Male } \\
\text { Female }\end{array}$ & $\begin{array}{l}320 \\
307\end{array}$ & $\begin{array}{l}51 \cdot 0 \\
49 \cdot 0\end{array}$ \\
\hline $\begin{array}{l}\text { Occupational status } \\
\text { White collar workers } \\
\text { Clerks and salesmen } \\
\text { Blue collar workers } \\
\text { Others }\end{array}$ & $\begin{array}{r}168 \\
144 \\
234 \\
81\end{array}$ & $\begin{array}{l}26 \cdot 8 \\
23 \cdot 0 \\
37.3 \\
12 \cdot 9\end{array}$ \\
\hline $\begin{array}{l}\text { Living conditions } \\
\text { Alone } \\
\text { Outside WC } \\
\text { Access to home }>10 \text { steps }\end{array}$ & $\begin{array}{r}188 \\
60 \\
248\end{array}$ & $\begin{array}{r}30 \cdot 1 \\
99.6 \\
39.7\end{array}$ \\
\hline $\begin{array}{l}\text { Mean age in years (SD) } \\
\text { at interview } \\
\text { at retirement }\end{array}$ & \multicolumn{2}{|c|}{$\begin{array}{l}69.0(4.0) \\
63.0(3.5)\end{array}$} \\
\hline
\end{tabular}

Table III Prevalence of physical disability and impairments

\begin{tabular}{|c|c|c|}
\hline & $\begin{array}{l}\text { Number of subjects } \\
(n=627)\end{array}$ & Percentage \\
\hline $\begin{array}{l}\text { Physical disability } \\
\text { No difficulties or need for help in ADL } \\
\text { Difficulties in ADL } \\
\text { Difficulties requiring help in ADL }\end{array}$ & $\begin{array}{r}439 \\
130 \\
58\end{array}$ & $\begin{array}{r}70.0 \\
20.7 \\
9.3\end{array}$ \\
\hline $\begin{array}{l}\text { Impairments } \\
\text { None } \\
\text { Musculoskeletal } \\
\text { Cardiorespiratory } \\
\text { Audiovisual } \\
\text { Digestive } \\
\text { Mental }\end{array}$ & $\begin{array}{r}110 \\
384 \\
235 \\
243 \\
68 \\
66\end{array}$ & $\begin{array}{l}17.5 \\
61 \cdot 2 \\
37.5 \\
38.8 \\
10 \cdot 8 \\
10.5\end{array}$ \\
\hline Number of impairments per subject, mean (SD) & $1 \cdot 6(1 \cdot 1)$ & \\
\hline
\end{tabular}

$\overline{\mathrm{a}^{\mathrm{ADL}}}=$ activities of daily life

Table IV Percentage of subjects exposed to each occupational risk factor during working life according to category of physical disability after retirement

\begin{tabular}{|c|c|c|c|c|}
\hline \multirow[b]{2}{*}{$\begin{array}{l}\text { Occupational } \\
\text { risk factors } \\
\text { (number of subjects at risk) }\end{array}$} & \multicolumn{4}{|l|}{ Physical disability } \\
\hline & $\begin{array}{l}\text { No difficulties } \\
\text { or need for help } \\
\text { in } A D L^{\mathrm{a}} \\
(n=439)\end{array}$ & $\begin{array}{l}\text { Difficulties } \\
\text { in } A D L \\
(n=130)\end{array}$ & $\begin{array}{l}\text { Difficulties } \\
\text { requiring help } \\
\text { in } A D L \\
(n=58)\end{array}$ & $p$ \\
\hline $\begin{array}{l}\text { Noise (89) } \\
\text { Heat (42) } \\
\text { Bad weather (67) } \\
\text { Dust (81) } \\
\text { Toxic products (48) } \\
\text { Carrying heavy load (88) } \\
\text { Awkward postures (122) } \\
\text { Vibrations (40) }\end{array}$ & $\begin{array}{r}12 \cdot 8 \\
5 \cdot 9 \\
10 \cdot 3 \\
10 \cdot 7 \\
6 \cdot 6 \\
11 \cdot 6 \\
17 \cdot 1 \\
5 \cdot 0\end{array}$ & $\begin{array}{r}13 \cdot 9 \\
5 \cdot 4 \\
10 \cdot 8 \\
13 \cdot 1 \\
8 \cdot 5 \\
16 \cdot 2 \\
23 \cdot 1 \\
8 \cdot 5\end{array}$ & $\begin{array}{l}25 \cdot 9 \\
15 \cdot 5 \\
12 \cdot 1 \\
29 \cdot 3 \\
13 \cdot 8 \\
27 \cdot 6 \\
29 \cdot 3 \\
12 \cdot 1\end{array}$ & $\begin{array}{l}\star \\
\star \\
N S \\
\pm \\
N S \\
t \\
\star \\
\text { NS }\end{array}$ \\
\hline $\begin{array}{l}\text { Number of occupational } \\
\text { risk factors, mean (SD) }\end{array}$ & $0.8(1.4)$ & $1.0(1.6)$ & $1 \cdot 7(2 \cdot 2)$ & $\mp$ \\
\hline
\end{tabular}

reported difficulties in at least one of these activities, and $10 \%$ required help for at least one.

Only $17.5 \%$ of the subjects reported absence of impairment. The three most frequent impairments were musculoskeletal $(61.2 \%)$, cardiorespiratory $(37.5 \%)$, and audiovisual $(38.8 \%)$ One third of the subjects $(33.5 \%)$ stated they had one impairment and $49 \%$ that they had more than two. The mean number of impairments was 1.6 (SD 1.1).

Table IV shows the percentages of subjects exposed to each risk factor during working life, according to the category of physical disability experienced after retirement. Statistically significant relationships were shown between physical disability and noise $(p<0.03)$, heat $(p<0.02)$, exposure to dust $(p<0.001)$, carrying heavy loads $(\mathrm{p}<0.003)$, and awkward postures $(\mathrm{p}<0.04)$. For vibrations, the relationship did not quite reach significance $(p<0.07)$. Whatever the risk factor considered, the percentage of subjects exposed varied homogeneously with the category of disability. The proportion of exposed subjects was clearly highest among the group of subjects requiring help in basic daily life activities. There was also a statistically significant relationship between the mean number of occupational risk factors to which subjects were exposed and the category of disability.

Table V shows the distribution of each sociodemographic variable and the prevalence of each type of impairment among the three categories of disability. There were statistically significant relationships between each of these categories and all the variables studied except for age and living alone. The distributions of the sociodemographic variables were much the same among subjects who experienced difficulties in basic daily life activities and those who needed help. On the other hand, there were significantly more impairments, irrespective of type, among people requiring help with daily activities than among people not requiring help.

Table VI shows the percentage of subjects exposed to each occupational risk factor during working life, according to the presence or absence of musculoskeletal impairment on one hand and cardiorespiratory impairment on the other hand. Two risk factors were significantly related to the presence of musculoskeletal impairment: carrying heavy loads $(p<0.05)$ and working in awkward postures $(p<0.05)$. Cardiorespiratory impairment was significantly related to all the occupational risk factors except heat and bad weather. Moreover there was a significant correlation between exposure to vibrations and the presence of mental impairment $(p<0.05)$. On the other hand, no correlation was found between occupational risk factors and audiovisual or digestive impairment.

Table VII shows the results of the three separate models. In the first model concerning sociodemographic variables, three variables were each linked with physical disability: sex, occupational status, and having a lavatory outside the home. In the second model concerning impairments, three variables were separately linked with physical disability: musculoskeletal impairment, cardiorespiratory impairment, and audiovisual impairment. In the third model concerning occupational 
variables, carrying heavy loads was the only item related to physical disability.

Table VIII gives the odds ratios derived from the general model for the variables which in each of the three separate models were found to

Table $V$ Sociodemographic factors and impairments (\%) according to category of physical disability after retirement

\begin{tabular}{|c|c|c|c|c|}
\hline & \multicolumn{4}{|c|}{ Physical disability } \\
\hline & $\begin{array}{l}\text { No difficulties } \\
\text { or need for help } \\
\text { in } A D L^{\mathrm{a}} \\
(n=439)\end{array}$ & $\begin{array}{l}\text { Difficulties } \\
\text { in } A D L \\
(n=130)\end{array}$ & $\begin{array}{l}\text { Difficulties } \\
\text { requiring help } \\
\text { in } A D L \\
(n=58)\end{array}$ & $p$ \\
\hline $\begin{array}{l}\text { Sociodemograpic factors } \\
\text { Mean age in years (SD) } \\
\text { Sex (\% of men) } \\
\text { Occupational status } \\
\text { Living alone } \\
\text { Outside WC } \\
\text { Access to home }>10 \text { steps }\end{array}$ & $\begin{array}{l}68 \cdot 4(3 \cdot 4) \\
54 \cdot 9 \\
31 \cdot 5 \\
27 \cdot 6 \\
7 \cdot 5 \\
37 \cdot 8\end{array}$ & $\begin{array}{l}68 \cdot 5(4 \cdot 2) \\
42 \cdot 3 \\
15 \cdot 6 \\
37 \cdot 7 \\
14 \cdot 6 \\
48 \cdot 5\end{array}$ & $\begin{array}{l}68 \cdot 8(3 \cdot 8) \\
41 \cdot 4 \\
18 \cdot 9 \\
31 \cdot 0 \\
13 \cdot 8 \\
32 \cdot 8\end{array}$ & \begin{tabular}{l} 
NS \\
${ }^{\dagger}$ \\
\multirow{\star}{*}{} \\
$\star$
\end{tabular} \\
\hline $\begin{array}{l}\text { Impairments } \\
\text { Musculoskeletal } \\
\text { Cardiorespiratory } \\
\text { Audovisual } \\
\text { Digestive } \\
\text { Mental }\end{array}$ & $\begin{array}{r}55 \cdot 1 \\
27 \cdot 1 \\
34 \cdot 2 \\
7 \cdot 5 \\
6 \cdot 6\end{array}$ & $\begin{array}{l}74 \cdot 5 \\
59 \cdot 2 \\
43 \cdot 1 \\
20 \cdot 8 \\
17 \cdot 7\end{array}$ & $\begin{array}{l}77 \cdot 6 \\
67 \cdot 2 \\
63 \cdot 8 \\
13 \cdot 8 \\
24 \cdot 1\end{array}$ & $\begin{array}{l}\ddagger \\
\ddagger \\
\ddagger \\
\ddagger \\
\ddagger \\
\ddagger\end{array}$ \\
\hline Number of impairments, mean (SD) & $1 \cdot 3(1 \cdot 0)$ & $2 \cdot 2(1 \cdot 1)$ & $2 \cdot 5(1 \cdot 2)$ & \\
\hline
\end{tabular}

Table VI Percentage of subjects exposed to each occupational risk factor during working life according to the two more frequent impairments.

\begin{tabular}{|c|c|c|c|c|c|c|}
\hline \multirow[b]{2}{*}{$\begin{array}{l}\text { Occupational } \\
\text { risk factors }\end{array}$} & \multicolumn{3}{|c|}{ Musculoskeletal impairment } & \multicolumn{3}{|c|}{ Cardiorespiratory impairmen } \\
\hline & $\begin{array}{l}\text { Without } \\
(n=243)\end{array}$ & $\begin{array}{l}\text { With } \\
(n=384)\end{array}$ & $p$ & $\begin{array}{l}\text { Without } \\
(n=392)\end{array}$ & $\begin{array}{l}\text { With } \\
(n=235)\end{array}$ & $p$ \\
\hline $\begin{array}{l}\text { Noise } \\
\text { Heat } \\
\text { Bad weather } \\
\text { Dust } \\
\text { Toxic products } \\
\text { Carrying heavy loads } \\
\text { Awkward postures } \\
\text { Vibration }\end{array}$ & $\begin{array}{r}14 \cdot 0 \\
5.4 \\
11.1 \\
11.9 \\
6 \cdot 2 \\
9.9 \\
15 \cdot 2 \\
4.5\end{array}$ & $\begin{array}{r}14 \cdot 3 \\
7 \cdot 6 \\
10 \cdot 2 \\
13 \cdot 5 \\
8 \cdot 6 \\
16 \cdot 7 \\
22 \cdot 1 \\
7 \cdot 6\end{array}$ & $\begin{array}{l}\text { NS } \\
\text { NS } \\
\text { NS } \\
\text { NS } \\
\text { NS } \\
\star \\
\text { NS }\end{array}$ & $\begin{array}{r}11 \cdot 0 \\
5 \cdot 6 \\
9 \cdot 7 \\
9 \cdot 7 \\
5 \cdot 1 \\
11 \cdot 7 \\
14 \cdot 8 \\
3 \cdot 6\end{array}$ & $\begin{array}{r}19 \cdot 6 \\
8 \cdot 5 \\
11 \cdot 9 \\
18 \cdot 3 \\
11 \cdot 9 \\
17 \cdot 9 \\
27 \cdot 2 \\
11 \cdot 1\end{array}$ & $\begin{array}{l}t \\
\text { NS } \\
\text { NS } \\
t \\
t \\
\star \\
\pm \\
\pm\end{array}$ \\
\hline
\end{tabular}

${ }^{\star} \mathrm{p}<0.05 ; \mathrm{tp}<0.01 ; \neq \mathrm{p}<0.001$

Table VII Logistic regression analysis: separate models for physical disability

\begin{tabular}{|c|c|c|c|}
\hline Explanatory variables & $O R$ & $95 \% C I$ & $p$ \\
\hline $\begin{array}{l}\text { First model: Sociodemographic variables } \\
\text { Age } \\
\text { Sex } \\
\text { Occupational status } \\
\text { Living alone } \\
\text { Outside WC } \\
\text { Access to home }>10 \text { steps }\end{array}$ & $\begin{array}{l}\overline{1} \cdot 4 \\
1.9 \\
\overline{1} \cdot 7 \\
-\end{array}$ & $\begin{array}{l}\overline{[1 \cdot 0,2 \cdot 0]} \\
{[1 \cdot 2,3 \cdot 1]} \\
\overline{[1} \cdot 0,3 \cdot 0]\end{array}$ & $\begin{array}{l}\text { NS } \\
\star \\
\pm \\
\text { NS } \\
\text { NS }\end{array}$ \\
\hline $\begin{array}{l}\text { Second model: Impairment variables } \\
\text { Musculoskeletal } \\
\text { Cardiorespiratory } \\
\text { Audiovisual } \\
\text { Digestive } \\
\text { Mental }\end{array}$ & $\begin{array}{l}2 \cdot 4 \\
4 \cdot 3 \\
1 \cdot 8 \\
- \\
-\end{array}$ & $\begin{array}{l}{[1 \cdot 6,3 \cdot 7]} \\
{[3 \cdot 0,6 \cdot 3]} \\
{[1 \cdot 2,2 \cdot 7]} \\
- \\
-\end{array}$ & $\begin{array}{l}\ddagger \\
\pm \\
\ddagger \\
\text { NS } \\
\text { NS }\end{array}$ \\
\hline $\begin{array}{l}\text { Third model: Occupational risk factor variables } \\
\text { Noise } \\
\text { Heat } \\
\text { Bad weather } \\
\text { Dust } \\
\text { Toxic products } \\
\text { Carrying heavy loads } \\
\text { Awkward posture } \\
\text { Vibration }\end{array}$ & $\begin{array}{l}- \\
- \\
- \\
\overline{-} \\
1 \cdot 8 \\
-\end{array}$ & $\begin{array}{l}- \\
- \\
- \\
\overline{-} \\
{[1 \cdot 1,2 \cdot 9]} \\
-\end{array}$ & $\begin{array}{l}\text { NS } \\
\text { NS } \\
\text { NS } \\
\text { NS } \\
\text { NS } \\
+ \\
\text { NS } \\
\text { NS }\end{array}$ \\
\hline
\end{tabular}

Table VIII Logistic regression analysis: general models for physical disability

\begin{tabular}{|c|c|c|c|c|c|c|}
\hline \multirow[b]{2}{*}{ Explanatory variables } & \multicolumn{3}{|c|}{ First model } & \multicolumn{3}{|c|}{ Second model ${ }^{\mathrm{a}}$} \\
\hline & $\overline{O R}$ & $95 \% \mathrm{CI}$ & $p$ & $O R$ & $95 \% C I$ & $p$ \\
\hline $\begin{array}{l}\text { Sex } \\
\text { Occupational status } \\
\text { Outside WC } \\
\text { Musculoskeletal impairment } \\
\text { Cardiorespiratory impairment } \\
\text { Audiovisual impairment } \\
\text { Carrying heavy loads }\end{array}$ & $\begin{array}{l}\overline{1 \cdot 7} \\
\overline{2} \cdot 3 \\
4 \cdot 0 \\
1 \cdot 8 \\
-\end{array}$ & $\begin{array}{l}- \\
{[1 \cdot 0,2 \cdot 7]} \\
- \\
{[1 \cdot 5,3 \cdot 5]} \\
{[2 \cdot 7,5 \cdot 8]} \\
{[1 \cdot 2,2 \cdot 6]}\end{array}$ & $\begin{array}{l}\text { NS } \\
\star \\
\text { NS } \\
\dagger \\
\ddagger \\
\dagger \\
\text { NS }\end{array}$ & $\begin{array}{l}1.6 \\
- \\
2 \cdot 2 \\
4 \cdot 3 \\
1.9 \\
1.7\end{array}$ & $\begin{array}{l}{[1 \cdot 1,2 \cdot 4]} \\
- \\
{[1 \cdot 4,3 \cdot 3]} \\
{[2 \cdot 9,6 \cdot 2]} \\
{[1 \cdot 3,2 \cdot 7]} \\
{[1 \cdot 0,2 \cdot 9]}\end{array}$ & $\begin{array}{l}\star \\
\text { NS } \\
\ddagger \\
\ddagger \\
\ddagger \\
\star\end{array}$ \\
\hline
\end{tabular}

Carrying heavy loads

${ }^{a}$ Without occupational status

$\mathrm{OR}=$ odds ratio; $\mathrm{CI}=$ confidence interval

${ }^{\star} \mathrm{p}<0.05 ; \mathrm{tp}<0.01 ; \neq \mathrm{p}<0.001$ correlate significantly with physical disability. There are two general models. The first model included all the variables and the second model excluded one variable-the occupational status-to take into account a possible overadjustment. In the first model, occupational status and the three main impairments were each correlated with physical disability. Carrying heavy loads was not related to physical disability. In the second general model, the three main impairments were still correlated with physical disability but sex and carrying heavy loads were also significantly correlated with physical disability. We checked that there was no statistical interaction between sex, occupational status, and carrying heavy loads on the one hand, and physical disability on the other.

\section{Discussion}

In this study of a group of retired men and women living at home in the Paris area, we showed significant relationships between the presence of physical disability after retirement and exposure during working life to noise, heat, dust, carrying heavy loads, and working in awkward postures. These relationships were not independent of the presence of musculoskeletal, cardiorespiratory, and audiovisual impairment, or of occupational status. Exposure to carrying heavy loads nevertheless seemed to be specifically linked to the presence of physical disability, when overadjustment for occupational status was taken into account.

The percentage of respondents in our survey was close to the usual proportion in studies of elderly populations interviewed at home. ${ }^{19}$ Among non-responders, $33 \%$ claimed to have serious diseases, $28.9 \%$ were not interested in being involved in the study, $19.6 \%$ could not be traced, and $18.6 \%$ were subjects without any indications. So illness at the time of the study was the reason for non-participation in about one third of the subjects. No statistically significant differences between respondents and nonrespondents were found for age or sex.

The present sample is still being followed up for mortality. After eight years of follow up, the cumulative incidence of mortality seems similar for respondents and non-respondents $(25.9 \%$ of the respondents and $24.4 \%$ of the non-respondents among the men, and $8.1 \%$ and $9.9 \%$ respectively among the women). We can assume from this observation that those who participated in the study had not been selected on the basis of health factors related to mortality. In addition, examination of the job records of responders and nonresponders supplied by the supplementary pension fund showed no significant differences between the two groups, particularly with regard to the mean number of branches of economic activity and firms in which the subjects had worked. ${ }^{14}$ However, one difficulty in our study is the possibility that there might be different response rates in the different occupational or disability classes.

The sample was composed of beneficiaries of a particular supplementary pension fund. It consisted of a specially selected group of retired people who had been through all the selections experienced during active working life, were still alive at 
the time of the study, and were living at home. It is likely that the subjects in the poorest health, whose health status may have been connected with the occupational exposures studied, had already died ${ }^{20}$ or were living in institutions. This possibility might weaken the relationship we observed between occupational exposures in the past and disability after retirement.

It should also be noted that most of the members of this supplementary pension fund come from private economic sectors that do not include retired persons from the public sector, so that our results cannot be extended to retired people as a whole.

The absence of a relationship between age and physical disability, an unusual finding in this type of survey, was probably due to the small range of ages in our sample and to the presence of few subjects aged over 75 years.

When in the course of retrospective surveys retired subjects are asked to identify the risk factors encountered during their working life, they usually have to rely on their memory. Self reported work history has been shown to be valid by comparison with occupational records. ${ }^{21}$ In this study we attempted to limit inaccuracies due to the subjective recall of work history by using a period of over 10 years to define exposure to each occupational risk factor. However, as we were interviewing a sample of elderly subjects six years (on average) after their retirement, lapses of memory may have been greater than usual. ${ }^{22}$ It may also be that exposure to risk factors during working life is remembered more clearly with declining health, and the subject may suspect that there is a link between past work and present poor health. To limit this bias to a certain extent, we informed neither the interviewers nor those interviewed of the relationship being studied. After the survey, a group of specialists in industrial health, including occupational physicians and experts in ergonomics, was asked to analyse the work histories of the subjects and to grade exposure to each risk factor as unlikely, possible, or very probable on the basis of a single item of information, ie, the job in which each subject had worked for longest. Comparison of the viewpoints of the subjects and the specialists tend to show that subjects underestimated their exposure. Therefore it may be assumed that some mistakes were made in classifying exposure and that if they could be corrected, the statistical relationships we found would be strengthened.

As usual in this type of survey, assessment of physical disability also depends on the statements made by the subjects. ${ }^{23}$ Despite the simplicity of the questions asked to evaluate disability, we cannot rule out the possibility that subjects perceived the questions differently, depending on their social class or educational level. The results show a link between social class and physical disability.

The traditional risk factors of smoking, alcohol consumption, and high blood pressure, combined with lifestyle, might also play a part in the relationship between occupational exposure and physical disability. In our sample there were no significant differences between the distributions of smoking and high blood pressure $(49.9 \%$ of smokers and $14.8 \%$ with high blood pressure among those reporting physical disability, versus $47.7 \%$ and $11.7 \%$ among those reporting no disability). As regards alcohol consumption, the proportion of subjects who said they consumed alcoholic beverages was significantly higher in the group with no disability ( $43 \%$, versus $33 \%$ for the disabled). Futhermore, in the multivariate analysis, the fact that cardiorespiratory, digestive, mental, and musculoskeletal impairments were taken into account can be considered an indirect way of adjusting for these possible confounding factors.

To sum up, the different types of bias just reviewed do not seem to us to cast doubt on the relationships shown in this study. Roupe and Svanbörg ${ }^{13}$ already found links between the normal worker's occupational past and the presence of auditory and pulmonary impairments known to cause disability. Subsequently, Brisson et al $^{\mathbf{2 4}}$ showed a relationship between the duration of employment in piecework employment and the prevalence of severe impairment, measured against the ability to perform common activities, in a sample of 533 Quebec women textile workers aged 45 to 70 years. The relationship was independent of age, smoking habits, educational level, and of the type and duration of the tasks performed during working life. The duration of piecework employment was also linked to musculoskeletal impairment and to a lesser extent to cardiovascular impairment.

In our survey, two factors - occupational status and the presence of impairments-are each related to physical disability. This result agrees with the findings of previous studies, although the link between occupational status and physical disability after retirement has not so far been extensively studied. ${ }^{25}$ The relationship between occupational risk factors and physical disability seems to be accounted for by the connection shown in our sample between certain types of exposure and certain impairments.

Considerable exposure to certain risk factors is known to cause impairments that lead to disability: for instance, noise can cause deafness and dust can cause chronic bronchitis. However, our results also suggest that carrying heavy loads for more than 10 years during working life might have its own specific effect on the existence of physical disability after retirement, quite apart from any musculoskeletal and/or cardiorespiratory impairment, if the overadjustment for social class is taken into account. ${ }^{26}$ This possibility seems similar to the observation already reported for risk factors for cardiovascular diseases, since in two studies 2728 these factors were found to be linked with physical disability in persons free of cardiovascular disease.

There is general agreeement that prevention of physical disability in old age should begin before retirement. Consequently, it is important not to forget the possible long term effects of occupational risk factors which, especially a long time after retirement, can affect the health of the elderly. These effects could explain in part the inequalities in health found in later life.

This study was funded by research grants from INSERM and CNAMTS. We wish to thank M Robert, director of IPSIE, $M$ Lellouch, director of 
INSERM U.169, and M Hémon, director of INSERM U.170, for their assistance and encouragement. We are also grateful to the subjects and their relatives who took part in the study.

1 Jette AM, Branch LG. Impairment and disability in the aged. F Chron Dis 1985; 38: 59-65.

2 Manton KG. Past and future life expectancy increases at later ages: their implications for the linkage of chronic morbidity, disability and mortality. $f$ Gerontol 1986; 41 : 672-81.

3 Jette AM, Branch LG. The Framingham disability study. II. Physical disability among the aging. Am $\mathcal{f}$ Public Health 1981; 71: 1211-6.

4 Palmore EB, Nowlin JB, Wang HS. Predictors of function among the old-old: a 10 year follow-up. $\mathcal{F}$ Gerontol 1985; 40: $244-50$

5 Manton KG. A longitudinal study of functional change and mortality in the United States. $f$ Gerontol 1988; 43: S153-61.

6 Svanbörg A Bergström G, Mellström D. Epidemiological studies on social and medical conditions of the elderly. Copenhagen: WHO, 1982

7 Harris T, Kovar MG, Suzman R, Kleinman JC, Feldman JJ. Longitudinal study of physical ability in the oldest-old. $A m$ f Public Health 1989; 79: 689-702.

8 Guralnik JM, Kaplan GA. Predictors of healthy aging: prospective evidence from the Alameda county study. $A m \mathcal{F}$ prospective evidence from the Alan
Public Health 1989; 79: 703-8.

9 Branch LG. Health practices and incident disability among the elderly. Am 7 Public Health 1985; 75: 1436-9.

10 Benfante R, Reed D, Brody J. Biological and social predictors of health in an aging cohort. $f$ Chron Dis 1985; 38: 385-95.

11 Mor V, Murphy J, Masterson-Allen S, et al. Risk of functional decline among well elders. $\mathcal{f}$ Clin Epidemiol 1989; 42: 895-904.

12 Pinsky JL, Leaverton PE, Stokes J. Predictors of good function: the Framingham study. $\mathcal{f}$ Chron Dis 1987; 40 (suppl 1): 159-67S.

13 Roupe S, Svanbörg A. Previous job and health at the age of 70. Scand f Soc Med 1981; 9: 25-31.
14 Iwatsubo Y, Derriennic F, Cassou B. Relation between job mobility during working life and health state after mobility during working life and health state anter retirement; a cross-sectional study of 627 subjects

15 Katz S, Ford AB, Moskowitz RW, Jackson BA, Jaffe NW. Studies of illness in the aged: a standardised measure of biological and psychosocial function. $\mathcal{F} A M A 1963 ; 185$ 914-9.

16 Rosow I, Breslau N. A Guttman health scale for the aged. $f$ Gerontol 1966; 21: 556-9.

17 Branch LG, Katz S, Kniepmann K, Papsidero JA. A prospective study of functional status among community elders. Am f Public Health 1984; 74: 266-8.

18 Langner TS. A twenty two items screening scores of psychiatric symptoms indicating impairment. 7 Health Human Behav 1962; 3: 219-76.

19 Kelsey JL, O'Brien LA, Grisso JA, Hoffmans S. Issues in carrying out epidemiologic research in the elderly. $A m \mathcal{F}$ carrying out epidemiologic

20 Markides KS, Machale KR. Selective survival, aging and society. Arch Gerontol Geriatr 1984; 3: 207-22.

21 Bourbonnais R, Meyer F, Theriault G. Validity of self reported work history. $\mathrm{Br} \mathcal{F}$ Ind Med 1988; 45: 29-32.

22 Coughlin SS. Recall bias in epidemiologic studies. $\mathcal{f}$ Clin Epidemiol 1990; 43: 87-91.

23 Feinstein AR, Josephy BR, Wells CK. Scientific and clinical problems in indexes of functional disability. Ann Intern Med 1986; 105: 413-20.

24 Brisson C, Vinet A, Vezina M, Gingras S. Effects of duration of employment in piecework on severe disability among female garment workers. Scand $\mathcal{f}$ Work Environ Health 1989; 15: 329-34.

25 Victor CR. Inequalities in health in latter life. Age Aging 1989; 18: 387-91.

26 Brisson C, Loomis D, Pearce N. Is social class standardisation appropriate in occupational studies? $f$ Epidemiol Community Health 1987; 41: 290-4.

27 Pinsky JL, Branch LG, Jette AM, et al. Framingham disability study: relationship of disability to cardio-vascular risk factors among persons free of diagnosed cardiovascular disease. Am $\mathcal{F}$ Epidemiol 1985; 122: 644-56.

28 Keil JE, Gazes PC, Sutherland SE, Rust PF, Branch LG Tyroler HA. Predictors of physical disability in elderly blacks and whites of the Charleston heart study, $f$ Clin Epidemiol 1989; 42: 521-9. 